\title{
University-Enterprise Cooperative Education Mode in the Context of Emerging Engineering Disciplines
}

\author{
https://doi.org/10.3991/ijet.v14i08.10396
}

\author{
Shan Zhong ( $\left.{ }^{\bowtie}\right)$, Xinmin Zhou \\ Wuhan University of Technology, Wuhan, China \\ zhongshan@whut.edu.cn
}

\begin{abstract}
From the strategic perspective of adapting to the development of economy in the new era, the Chinese Ministry of Education has recently proposed a new concept of "Emerging Engineering Disciplines", aiming to strengthen and deepen the reform and innovation of Chinese higher engineering education. The implementation of university-enterprise cooperative education to enhance students' innovative abilities is one of the focuses of that. With the new concept, this paper gives an account of a case study conducted at Wuhan University of Technology (WUT) to investigate the implementation plan of cooperative education between universities and enterprises. The universityenterprise cooperative education mode was introduced in the context of emerging trends in engineering. In this mode, universities and enterprises cooperate to formulate cultivation program, construct a practice training system and an open teaching system, trying to emerge the mechanisms of integrating social resources, a project-driven training, and a participation in entire industry process.
\end{abstract}

Keywords - Emerging engineering discipline; cooperative education between universities and enterprises; course system; engineering practice

\section{Introduction}

At present, China is promoting the innovation-driven development and implementing some important economic strategies, such as "One Belt and One Road", "Made in China 2025" and "Internet plus". The new economic strategies are represented by new technologies, formats, modes and industries [1]. In order to meet the demand of new economic development in China, it is of great importance for decision-makers, scientists and engineers to strengthen and deepen the reformation of engineering education, and further build a strong nation of engineering education. On February 18, 2017, Comprehensive Engineering Education of Universities Development Strategy Seminar was held at Fudan University of China. To meet the new economic demand for engineering education and challenge, the concept of "Emerging Engineering Disciplines" was proposed by the Fudan Consensus to build and develop a set of new engineering specialties based on demand-oriented industry, aiming to improve the current reform and innovation of engineering specialties. On 
April 8, 2017, Competitive Engineering and Polytechnic Universities Seminar on Emerging Engineering Disciplines was held at Tianjin University to discuss the roadmap for Emerging Engineering Disciplines construction (shown in Figure 1). The roadmap investigated and established a new paradigm of "TJU Operation" for engineering education development, and it experienced three transitions: from subject-oriented to demand-oriented industry, from professional division to crossborder and cross-integration, and from service adaptation to support and lead. On June 9, 2017, the Establishment and First Working Meeting of the Group of Emerging Engineering Disciplines Research and Practice Experts was held in Beijing Convention Center. The participating experts approved the "Guidelines for Emerging Engineering Disciplines and Practice Projects", and a "Beijing Guide" was formed to investigated the new concept of practical engineering education, new structure of engineering disciplines, new mode of talent cultivation, and new quality and diversity development system of education and teaching. The Fudan consensus, TJU Operation and Beijing Guide constitute the trilogy of Emerging Engineering Disciplines, playing the main role in the talent cultivation as well as opening a new path for the reformation of engineering education.

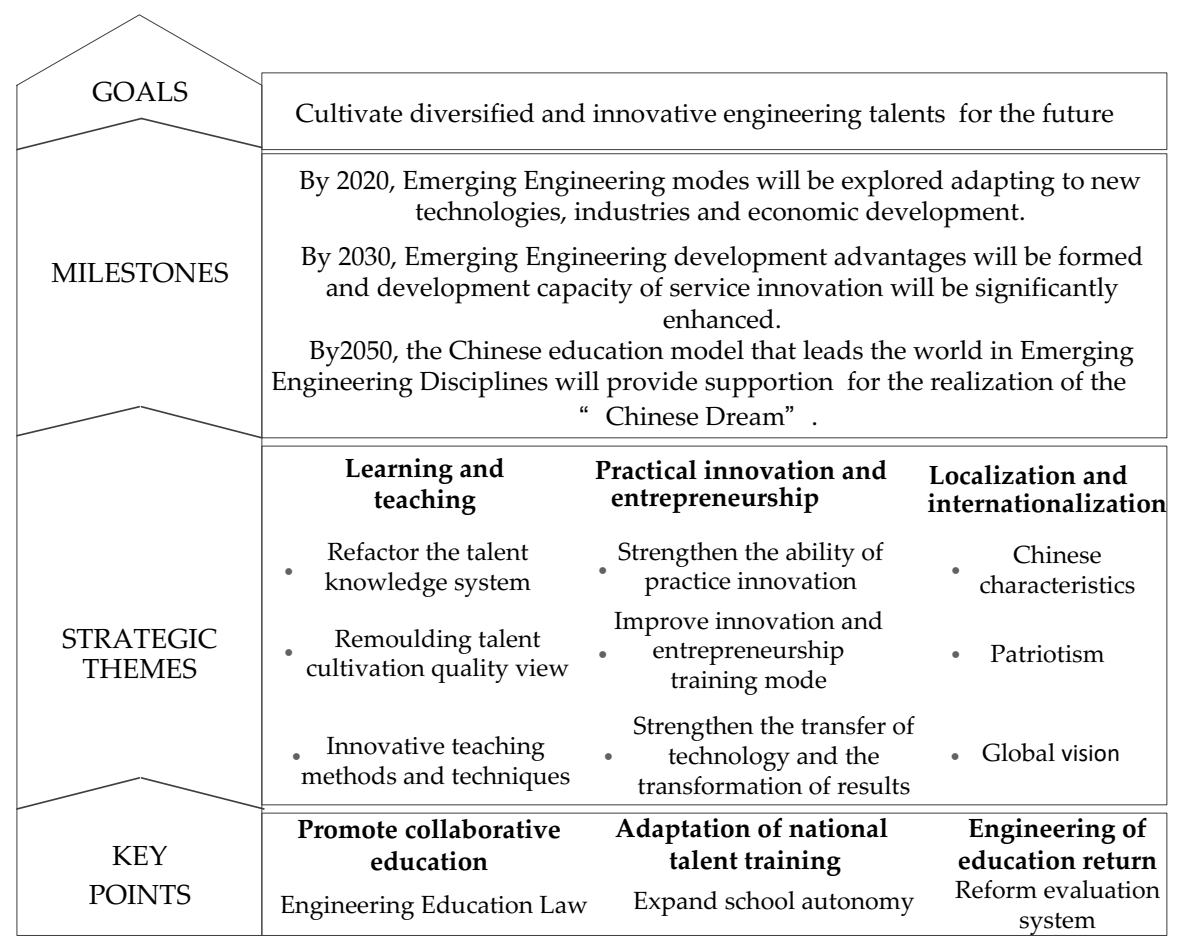

Fig. 1. Roadmap for Emerging Engineering Disciplines. 


\section{Basic Ideas on Practicing University-Enterprise Cooperative Education in Emerging Engineering Disciplines}

The content of University-enterprise cooperative education was embodied by the enrollment plan, the training plan, the theory of teaching practice, base installation construction, curriculum construction, scientific research and employment entrepreneurship teaching. At the same time School and enterprise cooperate deeply, which will benefit both them, leading to the last increase of the quality of cultivating talents and the technology of the production in enterprises [2]. The new economic development poses a challenge to the professional training of Emerging Engineering Disciplines professionals. Compared with the traditional engineering personnel, the emerging industries advance a new economic development demanding for highquality compound talents with strong engineering practice and innovation abilities [3]. The aim of Emerging Engineering Disciplines is to improve students' abilities of adaptation to change and engineering innovation, cultivate diversified and innovative excellent engineering personnel, solve the major challenges and problems of interpersonal relationships, and provide intellectual and talented support for the future. The talents cultivated by the Emerging Engineering Disciplines are characteristic of dealing with change, shaping the future, and the principal pathways of inheriting and innovating, crossing and blending, coordinating and sharing [4]. The top priority is the development of "Emerging Engineering Disciplines ", as well as new industry docking and training of technical personnel majoring in Engineering Disciplines [5].

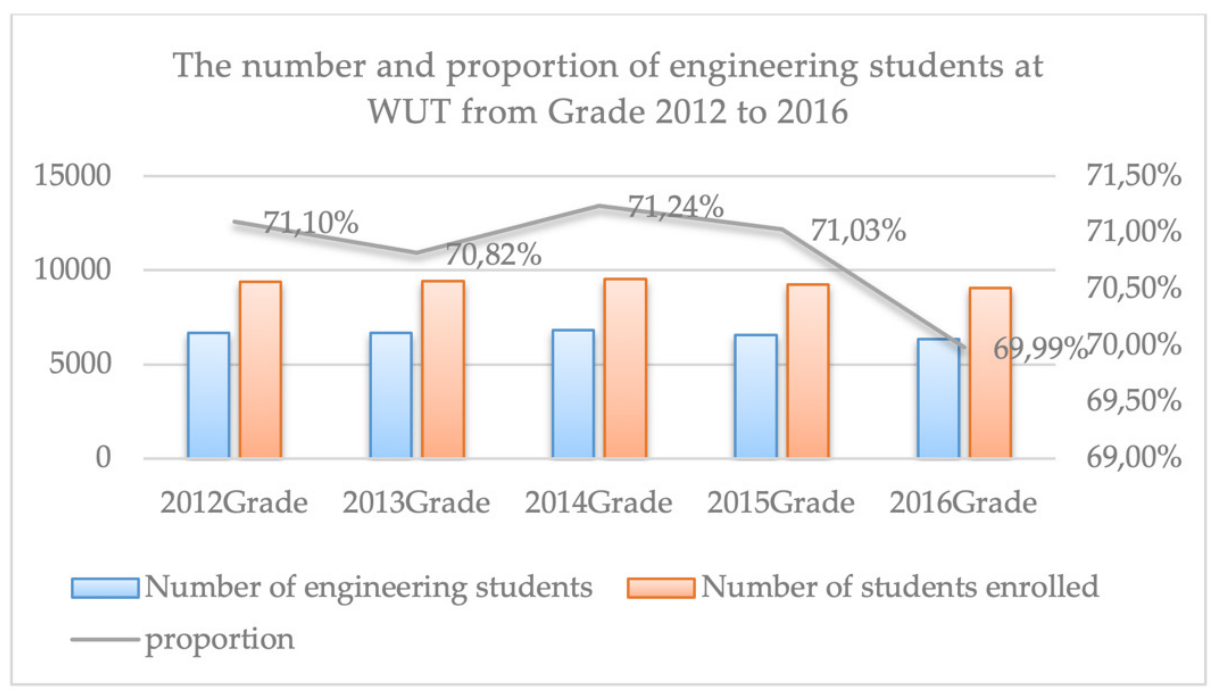

Fig. 2. The number and proportion of engineering students at WUT from Grade 2012 to 2016 
Wuhan University of Technology (WUT) is an important education base for highlevel personnel training with technological innovation in building material construction, transportation and automobiles in China. In the long-term university running practice, the university has formed a characteristic of "Three-Strong-Talent" for strong adaptability, strong ability to perform real deeds and strong innovative mind. The university now has 87 undergraduate majors, and over $70 \%$ of the undergraduates major in engineering disciplines from 2012 to 2016 (shown in Figure 2).Given that WUT has a large size of undergraduates and a wide range of specialties, the aim of exploration and practice on Emerging Engineering Disciplines at WUT is to promote the development of interdisciplinary subjects and rebuild university engineering professional training standards as well as knowledge structure, which relies on the university's unique advantages and undergraduate-centered collaborative education.

Taking advantage of the three major industries, the university takes the initiative to establish deep cooperation with other universities and enterprises based on the following strategies:

- Amending collaborative development of personnel training programs to meet the demand of innovative personnel in the industry, timely updating training objectives and curriculum system to ensure social compliance of personnel training;

- Auditing the content of courses with a timely introduction of cutting-edge technology and real business cases to ensure the effective teaching;

- Collaboratively building teaching teams with a combination of full-time and parttime teachers and training teachers with engineering practice abilities, which ensures the teaching quality;

- Carrying out the teaching process organization and implementation, so that students could get opportunities to watch the engineering scenes and communicate with professional/technical staffs directly, which could enhance the relevance of practical teaching;

- Monitoring and evaluating the coordination of teaching quality, getting over the practice of teaching problems and shortcomings, and establishing a continuous improvement mechanism for the practice teaching system.

\section{The Way of Implementing University-Enterprise Cooperative Education - Taking Automation Major at WUT as an Example}

The automation major of WUT is a pilot project of excellent engineer education. The training plan was approved by the Ministry of Education in 2011. Influenced by the strategies of "Industry 4.0" and "China manufacturing 2025", the traditional automation major needs more professional connotation. The undergraduates majoring in automation are required the abilities of cognition, design and execution [6]. By employing a group of outstanding professional and technical personnel of enterprise units and guiding undergraduate internship and graduation design, students can 
broaden their knowledge, and develop their practical ability according to "Double Teacher System" model of undergraduate training [7]. Especially in the context of "Emerging Engineering Disciplines" implementation, how to set up and reform university-enterprise cooperative training mode and develop the practical training mode to establish the teaching chain from theoretical study, hands-on practice to inquiry learning, achieving the goal of university-enterprise cooperative education are important issues as faced by the cultivation of automation professionals.

In the construction of automation specialty, we should promote deep universityenterprise cooperative education to build up a practical teaching platform via multipath, thus forming an open practice teaching system (shown in Figure 3). Based on the curricular system structure and relied on the practical teaching platform, the teaching system needs to strengthen the training of innovative capabilities and the training of innovative personnel [8]. According to the succession of courses and progressive relationship in the practical ability, a practical teaching plan can be gradually formed [9]. Under the background of Emerging Engineering Disciplines construction, automation major focuses on solving the following four problems in the aspect of university-enterprise cooperative education. First, how to build a theoretical and practical teaching system that is compatible with the industrial 4.0 era; Second, how to cooperate closely with enterprises, and establish a long-term cooperation mechanism between university and enterprise; Third, how to combine and join the intra-school training modes and university-enterprise training modes; Fourth, how to carry out the laboratory platform construction in line with the training system.

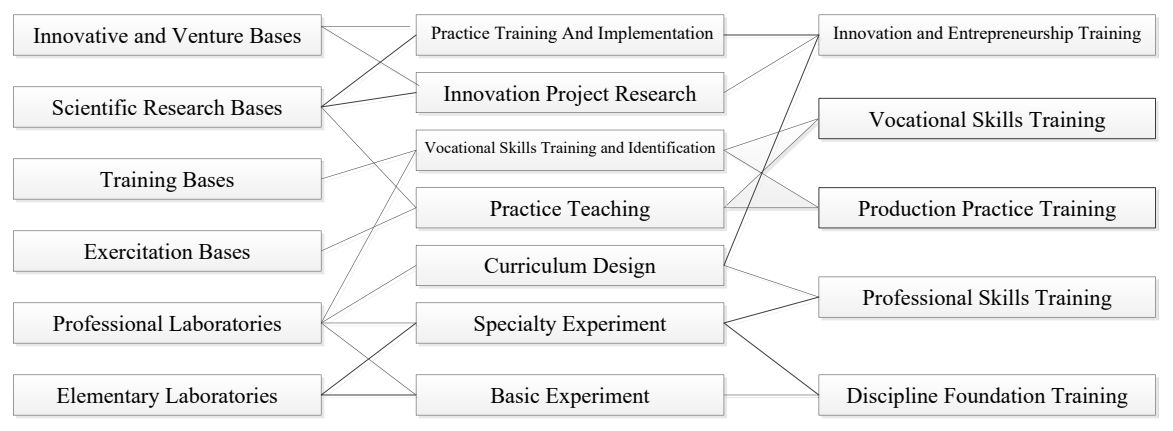

Fig. 3. The Open Practice Education System

\subsection{To meet the requirements of the times and the society}

In the face of the arrival of the industrial 4.0 era and the new needs of the society, significant changes will take place in the knowledge architecture of automation specialty. Considering the technical system of Industry 4.0 and automation specialty features, this paper proposes to construct knowledge system of automation specialty based on the principles of sensor detection, controller, automatic control theory, programming, actuator, generalized object, system interconnection and industrial 4.0 typical object. It is of theoretical significance and referential significance for the 
reconstruction of automation specialty knowledge architecture. In the aspect of practice teaching system, the experiment teaching system is mainly based on the project-driven comprehensive experiments of automation. Five stages, which are engineering design training, production practice, professional practice, job internship and graduation design, have been put forward to realizing the cultivation of engineering practice ability and to form the practice ability improvement mode.

\subsection{University and enterprises joint to construct the engineering education bases}

In order to implement practical teaching links for the students at the School of Automation, the school has constantly explored several ways to build a practical teaching platform. In 2014, the School of Automation put forward the construction idea of "School + Company + Brands", that is, the school-lead, company- implement and brands-participate. Here "School" is the School of Automation in WUT. "Company" is the Tongli Electro-Mechanic Co., Ltd. "Brands" include Siemens, Invoice Technology, ABB, Schneider, AB, LS Power, xiugLenze, Wuxi Hengda, etc. This is an opening and interactive base construction and an operation mode for engineering education. In the process of personnel training, the school, the company, and brands jointly decide the training objectives, formulate training program, and jointly implement the enterprise-stage practical teaching. According to the construction and operation mode of Engineering Practice Education Center, the university-enterprise education system in the enterprise stage is constructed by focusing on three aspects including "cognition", "practice" and "innovation". In 2015, "Wuhan University of Technology-Tongli Electro-Mechanic Excellence Engineer Engineering Practice Education Center" was awarded the "Hubei Provincial Model Practice Base". In the past two years, a total of nearly 180 students in excellent engineering pilot specialties for automation, electrical engineering and automation have completed the teaching stages, such as "Engineering Design Training", "Production Practice", "Job Internship" and "Graduation Project" at Tongli ElectroMechanic Co.

\subsection{To strengthen the cultivation of engineering practice ability}

In the school-based stage, project-driven teaching reformation is implemented. The university and school promote teaching method reformation, integrating teachers' research works, engineering projects and cases into course teaching process. In the extracurricular science and technology activities, based on the academic competition, innovative training programs for college students are conducted to build up guide teams of professional teachers provide guidance in the form of project training to enhance students' professional and practical ability and preliminary engineering practice ability.

During the university-enterprise joint training, five stages (engineering design training, production practice, professional practice, job internships, and graduation design) are joined together step by step, throughout all aspects of engineering 
practice. Engineering design training, production internship, professional practice lay the foundation for post internship. Engineering design and training enable students to master the engineering norms, project processes and basic skills of engineering practice. Professional practice, through the "Brands" participation in teaching process, broadens students' horizons in the field of view for students in the field of automation solutions and training of the most advanced automation technology. Job internship is carried out through implementation of project works, that is "Tender", "Bidding", "Implementation" and "Final acceptance of construction" abilities for engineering practice are improved through teaching, assessments and other different stages.

\subsection{Meeting requirements of the times and professional teaching system supporting}

A laboratory construction scheme is proposed to set up an industry 4.0 automation integrated experiment platform according to industrial 4.0 technology system, which supports the professional theory/practice teaching system. Independent comprehensive design, inquiry, and exploratory experimental courses are carried out based on robotics, management software as well as programming technology, network control technology, wireless network and sensor technology. The ability for engineering practice is strengthened by conducting systematic design and exploring experiment on the advanced automation technology platform.

\section{Effect of University - Enterprise Cooperative Education}

By promoting university and enterprise cooperation, the reformation and exploration in course teaching, practice training and academic competitions, will bring about a good situation of "docking, cooperation and win-win"[10]. To create a teaching environment through university and enterprise cooperation, schools and enterprises jointly decide the course settings according to the engineering demands so that the content of these courses could cover the actual work requirement and the course teaching could serve professional training [11]. WUT promotes university and enterprise cooperative education. The schools and enterprises jointly put forward works such as the cultivation plan formulation, construction of practice base, appointment of key teachers from enterprises, organization and implementation of teaching contents, establishing collaborative working mechanism, and implementation of student internship in the enterprise. WUT puts forth efforts on cultivation of students' engineering practice ability, so that a unique university-enterprise cooperative education mode is formed.

\subsection{The enthusiasm of part-time teachers from enterprises is enhanced significantly}

WUT has established a stable group of part-time teachers from enterprises in the talent training base according to the principle that "the teacher is appointed as part- 
time and teaching is based on the enterprise". The Department of Automation started its teaching practice of school-enterprise cooperative training since 2016. Twentythree part-time teachers from enterprises in total were appointed to teach 6 enterprise courses such as "Project Management", "Enterprise Independent Elective Courses", etc. The topics on engineering practice, which are accorded with talent training requirements, were prepared jointly by instructors in the school and part-time teachers from enterprises. In 2017, with the help of part-time teachers from enterprises, thirtyseven graduation designs (thesis) were finished by Excellent Engineer undergraduates. More than three hundred people were trained in professional practice, job internship and engineering design training. Based on the idea of project training, the internship students were divided into groups in different workshop production lines to complete product (or system) design and process design.

\subsection{Students innovative ability is improved obviously}

The practice base becomes an innovative practice base for college students. The topics including various subject competitions, independent innovation fund projects, national college students' innovation and entrepreneurship training programs, can be selected based on the enterprise demands or the actual productions. So, it could attract students to take part in the works in enterprise innovative practice projects. Students in Department of Automation are active in scientific and technological innovation activities. They have participated in many competitions such as Phoenix Global Automation Design Competition, Siemens Cup China Intelligent Manufacturing Challenge, Delta Cup Students Automation Design Contest, National Undergraduate Electronic Design Contest, etc. and won a lot of prizes (shown in Table 1). In the 2016-2017 academic year, 33 people won the international, national and provincial

Table 1. The prominent prize for discipline competitions won by the students in recent 3 years

\begin{tabular}{|l|c|l|l|l|}
\hline \multicolumn{1}{|c|}{ The name of competitions } & Award year & \multicolumn{1}{|c|}{ Award level } & Team leader & \multicolumn{1}{c|}{ Tutor } \\
\hline $\begin{array}{l}\text { TI-brand electronic design competition } \\
\text { of Hubei province }\end{array}$ & In 2017 & $\begin{array}{l}\text { Special-class award } \\
\text { of Hubei province }\end{array}$ & Shuran Jia & Xinmin Zhou \\
\hline $\begin{array}{l}\text { Siemens-brand intelligent manufacturing } \\
\text { challenge competition in China }\end{array}$ & In 2016 & National first prize & Kangyi Cheng & Xinmin Zhou \\
\hline $\begin{array}{l}\text { National university student Delta-brand } \\
\text { smart car competition }\end{array}$ & In 2016 & $\begin{array}{l}\text { First prize in south } \\
\text { China division. }\end{array}$ & Jihu Liao & $\begin{array}{l}\text { Qingyong } \\
\text { Zhang }\end{array}$ \\
\hline $\begin{array}{l}\text { Phoenix global automation grand prix } \\
\text { National university students social } \\
\text { practice and science contest on energy } \\
\text { conservation and emission reduction }\end{array}$ & In 2015 & The first prize & Xiaoqi Zhou & Jian Fu \\
\hline
\end{tabular}

A student science and technology innovation team named AT Group was built to improve students' innovative ability, practical spirit, and overall quality based on the technology competitions and research projects. The team has trained 104 scientific and technological innovation personnel and guided students to win 19 national or provincial awards. Moreover, 14 science and technology innovation projects have been finished. 


\subsection{The graduates are well-reputed by enterprises and institutions}

In recent years, the university has conducted a survey on the quality of personnel training for more than 100 employers who have employed graduates from automation students graduated in 2011-2016. The results show that the satisfaction rate of employers to the overall training quality of automation professionals was $96.59 \%$. Among them, the degree of satisfaction with the conformity of personnel training status and unit development was $94.32 \%$, satisfaction with job adaptability of graduates was $89.77 \%$, satisfaction with communication skills and teamwork ability was $95.45 \%$, professional knowledge satisfaction with the demand for job was $89.77 \%$, and satisfaction with self-learning and promotion ability was $95.46 \%$.

\subsection{The engineering skills of school instructors are significantly improved}

In accordance with the principle of "come in, go out", the university introduces excellent teachers to optimize the structure of teachers, and at the same time, makes the most of the advantage of national scientific research bases at WUT and joint training bases of industry and enterprises in training faculty. Besides, WUT supports teachers to take part in scientific research and engineering practice training in enterprises. Since 2011, the number of young teachers participating in practical ability improvement in schools has reached 799 , of which $70.2 \%$ of the teachers have completed practical training in relevant enterprises and institutions in the three industries. As of August 2016, 51.7\% of the teachers (science, technology and management) under the age of 45 have more than one year's experience in business practice or industry practice. To promote scientific research ability and engineering practice of full-time teachers, WUT has planned to formulate young and middle-aged full-time teachers to study or work aboard in recent years and then improve the teaching quality for the undergraduates.

\subsection{Students' satisfaction with practical teaching raises in a row}

WUT has relied on the interactions among the three industry boards to promote the talent cultivation, and realize the talent exchange, sharing resource and collaborative training of innovative talents through the joint construction with the industry enterprises; Relying on "excellence initiative" pilot discipline, we actively promote university-enterprise cooperative and joint training education, combine to set up education plans, construct practice base, engage enterprise backbone teachers, organize and implement the education content, establish collaborative work mechanism, implement the enterprise learning which focus on training students' engineering practical ability, form the synergy through colleges training mode containing school features. A special survey on students' internship in WUT was conducted by Wuhan Sowei business service co., LTD. According to the data in that, the students' satisfaction on the internship raised to $75.79 \%$ in $2014,79.24 \%$ in 2015 , $83.3 \%$ in 2016 and $89.93 \%$ in 2017 respectively (shown in Figure4). 


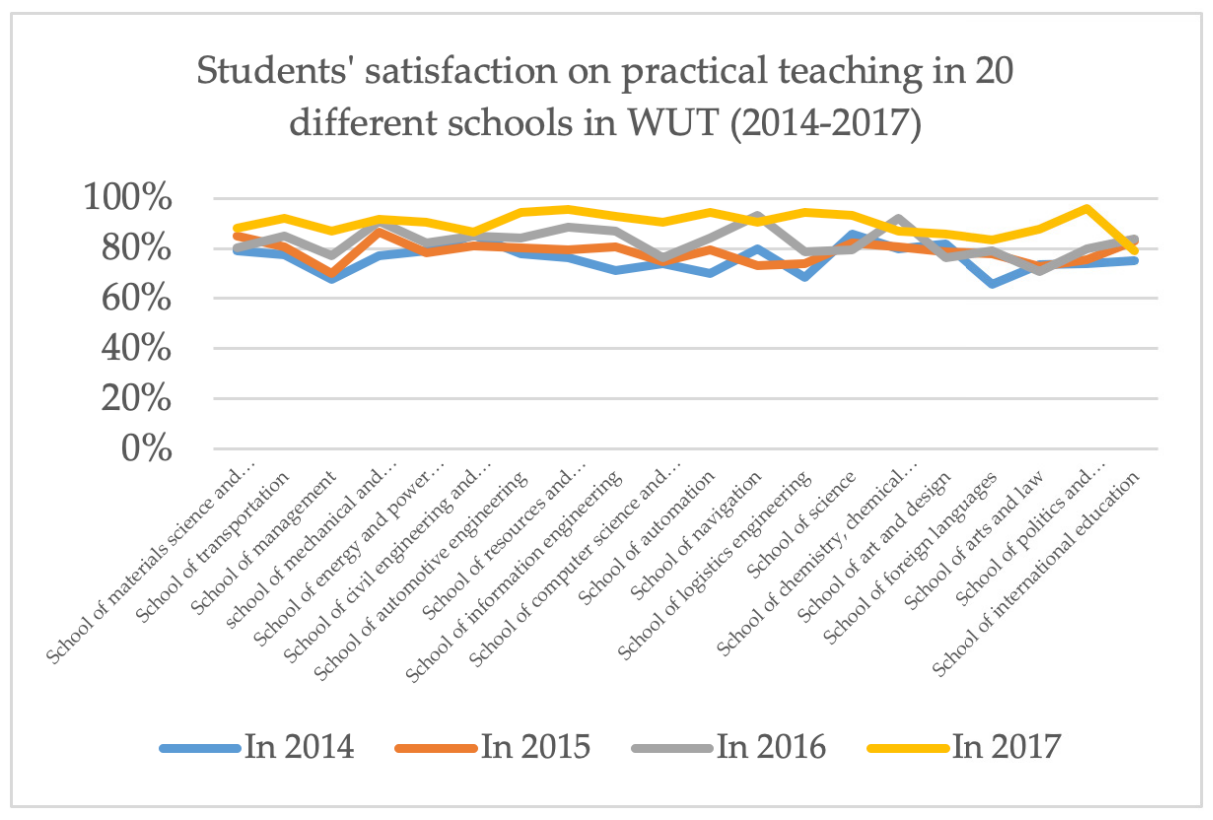

Fig. 4. Students' satisfaction on practical teaching in 20 different schools in WUT (20142017)

\section{The Affection of University-Enterprise Cooperative Education Mode in Outstanding Engineer Scheme}

The Outstanding Engineer Scheme emphasizes the deep involvement of industry enterprises in the talent cultivation, in accordance with the construction and operation mode of engineering practice education center, WUT put forward open and interactive University-Enterprise Cooperative Education Mode around three aspects such as cognitive and practice and innovation. WUT and other companies and brands shall jointly determine training objectives, formulate training programs and implement practical teaching at the enterprise stage. According to the statistics, the students in Excellent Engineer Class of Outstanding Engineer Scheme are superior to those in the non-pilot class in terms of the quality of graduation thesis, enrolment rate and innovation achievements of the competition.

The average proportion of provincial excellent papers of excellent engineering pilot major is $3.75 \%$, higher than the average of the whole school $2.68 \%$. The statistics of the number of students who have obtained outstanding bachelor's thesis in Hubei province and excellent rate of graduation thesis was shown in Table 2.

The average enrolment rate of school graduates going to further study was $31.47 \%$, and the average proportion of excellent pilot classes was $47.07 \%$, higher than the school average (shown in Table 3). 
The achievements obtained by the students of the Outstanding Engineer Scheme include published papers, projects, patents, and prizes for disciplines above the provincial level, etc., In the Excellent Engineer Class, $21.43 \%$ of the students have obtained innovative achievements during the various types of competition, and the statistics of innovative awards are shown in Table 4.

Table 2. The statistics about the quality of graduation thesis between Excellent Engineer Class and non-pilot class

\begin{tabular}{|c|c|c|c|c|c|c|c|c|}
\hline \multirow{3}{*}{$\begin{array}{l}\text { Major in Outstanding } \\
\text { Engineer Scheme }\end{array}$} & \multicolumn{4}{|c|}{$\begin{array}{l}\text { Outstanding bachelor's thesis in } \\
\text { Hubei province }\end{array}$} & \multicolumn{4}{|c|}{ Excellent rate of graduation thesis } \\
\hline & \multicolumn{2}{|c|}{$\begin{array}{c}\text { Excellent } \\
\text { Engineer Class }\end{array}$} & \multicolumn{2}{|c|}{ non-pilot class } & \multicolumn{2}{|c|}{$\begin{array}{c}\text { Excellent } \\
\text { Engineer Class }\end{array}$} & \multicolumn{2}{|c|}{ non-pilot class } \\
\hline & \begin{tabular}{|c|} 
The \\
number
\end{tabular} & \begin{tabular}{c|} 
The \\
proportion
\end{tabular} & $\begin{array}{c}\text { The } \\
\text { number }\end{array}$ & \begin{tabular}{|c|} 
The \\
proportion
\end{tabular} & $\begin{array}{c}\text { The } \\
\text { number }\end{array}$ & \begin{tabular}{|c|} 
The \\
proportion
\end{tabular} & $\begin{array}{c}\text { The } \\
\text { number }\end{array}$ & $\begin{array}{c}\text { The } \\
\text { proportion }\end{array}$ \\
\hline $\begin{array}{l}\text { Material forming and } \\
\text { control engineering }\end{array}$ & 0 & $0.00 \%$ & 5 & $3.60 \%$ & 19 & $61.29 \%$ & 96 & $69.06 \%$ \\
\hline $\begin{array}{l}\text { Naval Architecture and } \\
\text { Ocean Engineering }\end{array}$ & 1 & $3.13 \%$ & 4 & $2.27 \%$ & 32 & $100.00 \%$ & 132 & $75.00 \%$ \\
\hline Transportation & 1 & $3.70 \%$ & 1 & $3.03 \%$ & 25 & $92.59 \%$ & 26 & $78.79 \%$ \\
\hline Mechanical Engineering & 5 & $7.35 \%$ & 5 & $2.09 \%$ & 63 & $92.65 \%$ & 176 & $73.64 \%$ \\
\hline Packaging Engineering & 0 & $0.00 \%$ & 0 & $0.00 \%$ & 15 & $53.57 \%$ & 12 & $37.50 \%$ \\
\hline $\begin{array}{l}\text { Industrial Equipment and } \\
\text { Control Engineering }\end{array}$ & 2 & $5.56 \%$ & 1 & $1.69 \%$ & 27 & $75.00 \%$ & 38 & $64.41 \%$ \\
\hline $\begin{array}{l}\text { Measuring \& Control } \\
\text { Technology and Instrument }\end{array}$ & 1 & $2.86 \%$ & 2 & $1.30 \%$ & 31 & $88.57 \%$ & 79 & $51.30 \%$ \\
\hline $\begin{array}{l}\text { Energy \& Power } \\
\text { Engineering } \\
\text { (marine) }\end{array}$ & 1 & $2.94 \%$ & 7 & $5.56 \%$ & 34 & $100.00 \%$ & 101 & $80.16 \%$ \\
\hline Civil Engineering & 1 & $1.56 \%$ & 3 & $1.79 \%$ & 55 & $85.94 \%$ & 110 & $65.48 \%$ \\
\hline Automotive Engineering & 4 & $12.12 \%$ & 3 & $1.40 \%$ & 28 & $84.85 \%$ & 137 & $64.02 \%$ \\
\hline \begin{tabular}{|l} 
Energy \& Power \\
Engineering (automotive)
\end{tabular} & 3 & $9.38 \%$ & 2 & $1.85 \%$ & 28 & $87.50 \%$ & 74 & $68.52 \%$ \\
\hline $\begin{array}{l}\text { Automotive Support } \\
\text { Engineering }\end{array}$ & 1 & $2.94 \%$ & 1 & $0.90 \%$ & 29 & $85.29 \%$ & 69 & $62.16 \%$ \\
\hline $\begin{array}{l}\text { Mineral Processing } \\
\text { Engineering }\end{array}$ & 1 & $3.23 \%$ & 1 & $1.54 \%$ & 31 & $100.00 \%$ & 58 & $89.23 \%$ \\
\hline $\begin{array}{l}\text { Communication } \\
\text { Engineering }\end{array}$ & 1 & $3.45 \%$ & 4 & $2.05 \%$ & 19 & $65.52 \%$ & 110 & $56.41 \%$ \\
\hline $\begin{array}{l}\text { Computer Science \& } \\
\text { Technology }\end{array}$ & 1 & $1.56 \%$ & 3 & $2.36 \%$ & 54 & $84.38 \%$ & 66 & $51.97 \%$ \\
\hline Software Engineering & 3 & $4.29 \%$ & 1 & $1.28 \%$ & 62 & $88.57 \%$ & 63 & $80.77 \%$ \\
\hline Automation & 1 & $1.59 \%$ & 4 & $2.25 \%$ & 46 & $73.02 \%$ & 104 & $58.43 \%$ \\
\hline Engineering Mechanics & 2 & $6.67 \%$ & 1 & $1.67 \%$ & 26 & $86.67 \%$ & 43 & $71.67 \%$ \\
\hline Logistics Engineering & 2 & $3.77 \%$ & 2 & $3.51 \%$ & 38 & $71.70 \%$ & 45 & $78.95 \%$ \\
\hline $\begin{array}{l}\text { Chemical Engineering and } \\
\text { Technology }\end{array}$ & 1 & $3.57 \%$ & 2 & $2.67 \%$ & 25 & $89.29 \%$ & 65 & $86.67 \%$ \\
\hline Pharmaceutical Engineering & 0 & $0.00 \%$ & 1 & $1.75 \%$ & 19 & $59.38 \%$ & 35 & $61.40 \%$ \\
\hline Total & 32 & $3.75 \%$ & 53 & $2.16 \%$ & 706 & $82.67 \%$ & 1639 & $66.87 \%$ \\
\hline
\end{tabular}


Table 3. The status of the excellent pilot program enrolment rate for further study

\begin{tabular}{|c|c|c|c|c|c|c|}
\hline \multirow[b]{2}{*}{$\begin{array}{c}\text { Major in Outstanding } \\
\text { Engineer Scheme }\end{array}$} & \multicolumn{2}{|c|}{ The number of students } & \multicolumn{4}{|c|}{ The number of students for Graduate degrees } \\
\hline & $\begin{array}{c}\text { Excellent } \\
\text { Engineer } \\
\text { Class }\end{array}$ & $\begin{array}{l}\text { non-pilot } \\
\text { class }\end{array}$ & $\begin{array}{c}\text { Excellent } \\
\text { Engineer } \\
\text { Class }\end{array}$ & $\begin{array}{c}\text { The } \\
\text { proportion }\end{array}$ & $\begin{array}{l}\text { non-pilot } \\
\text { class }\end{array}$ & $\begin{array}{c}\text { The } \\
\text { proportion }\end{array}$ \\
\hline $\begin{array}{l}\text { Material forming and } \\
\text { control engineering }\end{array}$ & 31 & 139 & 10 & $32.26 \%$ & 50 & $35.97 \%$ \\
\hline $\begin{array}{l}\text { Naval Architecture and } \\
\text { Ocean Engineering }\end{array}$ & 32 & 176 & 24 & $75.00 \%$ & 64 & $36.36 \%$ \\
\hline Transportation & 27 & 33 & 14 & $51.85 \%$ & 8 & $24.24 \%$ \\
\hline $\begin{array}{l}\text { Mechanical } \\
\text { Engineering }\end{array}$ & 68 & 239 & 27 & $39.71 \%$ & 73 & $30.54 \%$ \\
\hline Packaging Engineering & 28 & 32 & 2 & $7.14 \%$ & 0 & $0.00 \%$ \\
\hline \begin{tabular}{|l|} 
Industrial Equipment \\
and Control \\
Engineering
\end{tabular} & 36 & 59 & 8 & $22.22 \%$ & 4 & $6.78 \%$ \\
\hline $\begin{array}{l}\text { Measuring \& Control } \\
\text { Technology and } \\
\text { Instrument }\end{array}$ & 35 & 154 & 21 & $60.00 \%$ & 29 & $18.83 \%$ \\
\hline \begin{tabular}{|l} 
Energy \& Power \\
Engineering(marine)
\end{tabular} & 34 & 126 & 23 & $67.65 \%$ & 35 & $27.78 \%$ \\
\hline Civil Engineering & 64 & 168 & 29 & $45.31 \%$ & 20 & $11.90 \%$ \\
\hline \begin{tabular}{|l|} 
Automotive \\
Engineering \\
\end{tabular} & 33 & 214 & 19 & $57.58 \%$ & 79 & $36.92 \%$ \\
\hline $\begin{array}{l}\text { Energy \& Power } \\
\text { Engineering ( } \\
\text { automotive })\end{array}$ & 32 & 108 & 22 & $68.75 \%$ & 22 & $20.37 \%$ \\
\hline $\begin{array}{l}\text { Automotive Support } \\
\text { Engineering }\end{array}$ & 34 & 111 & 16 & $47.06 \%$ & 20 & $18.02 \%$ \\
\hline $\begin{array}{l}\text { Mineral Processing } \\
\text { Engineering }\end{array}$ & 31 & 65 & 15 & $48.39 \%$ & 10 & $15.38 \%$ \\
\hline $\begin{array}{l}\text { Communication } \\
\text { Engineering }\end{array}$ & 29 & 195 & 20 & $68.97 \%$ & 72 & $36.92 \%$ \\
\hline $\begin{array}{l}\text { Computer Science \& } \\
\text { Technology }\end{array}$ & 64 & 127 & 29 & $45.31 \%$ & 29 & $22.83 \%$ \\
\hline Software Engineering & 70 & 78 & 23 & $32.86 \%$ & 18 & $23.08 \%$ \\
\hline Automation & 63 & 178 & 36 & $57.14 \%$ & 55 & $30.90 \%$ \\
\hline Engineering Mechanics & 30 & 60 & 23 & $76.67 \%$ & 21 & $35.00 \%$ \\
\hline Logistics Engineering & 53 & 57 & 21 & $39.62 \%$ & 41 & $71.93 \%$ \\
\hline $\begin{array}{l}\text { Chemical Engineering } \\
\text { and Technology }\end{array}$ & 28 & 75 & 8 & $28.57 \%$ & 33 & $44.00 \%$ \\
\hline \begin{tabular}{|l|} 
Pharmaceutical \\
Engineering
\end{tabular} & 32 & 57 & 12 & $37.50 \%$ & 16 & $28.07 \%$ \\
\hline Total & 854 & 2451 & 402 & $47.07 \%$ & 699 & $28.52 \%$ \\
\hline
\end{tabular}


Table 4. The achievements obtained by the students between Excellent Engineer Class and non-pilot class

\begin{tabular}{|c|c|c|c|c|c|c|}
\hline \multirow[b]{2}{*}{$\begin{array}{c}\text { Major in } \\
\text { Outstanding } \\
\text { Engineer Scheme }\end{array}$} & \multicolumn{2}{|c|}{ The number of students } & \multicolumn{2}{|c|}{ Excellent Engineer Class } & \multicolumn{2}{|c|}{ non-pilot class } \\
\hline & $\begin{array}{c}\text { Excellent } \\
\text { Engineer } \\
\text { Class }\end{array}$ & $\begin{array}{l}\text { non-pilot } \\
\quad \text { class }\end{array}$ & The number & $\begin{array}{c}\text { The } \\
\text { proportion }\end{array}$ & The number & $\begin{array}{c}\text { The } \\
\text { proportion }\end{array}$ \\
\hline $\begin{array}{l}\text { Material forming } \\
\text { and control } \\
\text { engineering }\end{array}$ & 31 & 139 & 9 & $29.03 \%$ & 0 & $0 \%$ \\
\hline $\begin{array}{l}\text { Naval Architecture } \\
\text { and Ocean } \\
\text { Engineering }\end{array}$ & 32 & 176 & 11 & $34.38 \%$ & 33 & $19 \%$ \\
\hline Transportation & 27 & 33 & 3 & $11.11 \%$ & 1 & $3 \%$ \\
\hline $\begin{array}{l}\text { Mechanical } \\
\text { Engineering } \\
\end{array}$ & 68 & 239 & 26 & $38.24 \%$ & 46 & $19 \%$ \\
\hline \begin{tabular}{|l|} 
Packaging \\
Engineering
\end{tabular} & 28 & 32 & 1 & $3.57 \%$ & 0 & $0 \%$ \\
\hline \begin{tabular}{|l|} 
Industrial \\
Equipment and \\
Control Engineering \\
\end{tabular} & 36 & 59 & 2 & $5.56 \%$ & 1 & $2 \%$ \\
\hline \begin{tabular}{|l|} 
Measuring \& \\
Control Technology \\
and Instrument
\end{tabular} & 35 & 154 & 8 & $22.86 \%$ & 16 & $10 \%$ \\
\hline \begin{tabular}{|l|} 
Energy \& Power \\
Engineering(marine) \\
\end{tabular} & 34 & 126 & 5 & $14.71 \%$ & 8 & $6 \%$ \\
\hline Civil Engineering & 64 & 168 & 27 & $42.19 \%$ & 24 & $14 \%$ \\
\hline $\begin{array}{l}\text { Automotive } \\
\text { Engineering }\end{array}$ & 33 & 214 & 10 & $30.30 \%$ & 74 & $35 \%$ \\
\hline $\begin{array}{l}\text { Energy \& Power } \\
\text { Engineering } \\
\text { (automotive) }\end{array}$ & 32 & 108 & 8 & $25.00 \%$ & 5 & $5 \%$ \\
\hline $\begin{array}{l}\text { Automotive Support } \\
\text { Engineering }\end{array}$ & 34 & 111 & 5 & $14.71 \%$ & 1 & $1 \%$ \\
\hline $\begin{array}{l}\text { Mineral Processing } \\
\text { Engineering }\end{array}$ & 31 & 65 & 1 & $3.23 \%$ & 0 & $0 \%$ \\
\hline $\begin{array}{l}\text { Communication } \\
\text { Engineering }\end{array}$ & 29 & 195 & 7 & $24.14 \%$ & 19 & $10 \%$ \\
\hline $\begin{array}{l}\text { Computer Science } \\
\& \text { Technology }\end{array}$ & 64 & 127 & 11 & $17.19 \%$ & 10 & $8 \%$ \\
\hline $\begin{array}{l}\text { Software } \\
\text { Engineering } \\
\end{array}$ & 70 & 78 & 14 & $20.00 \%$ & 19 & $24 \%$ \\
\hline Automation & 63 & 178 & 11 & $17.46 \%$ & 32 & $18 \%$ \\
\hline $\begin{array}{l}\text { Engineering } \\
\text { Mechanics } \\
\end{array}$ & 30 & 60 & 5 & $16.67 \%$ & 10 & $17 \%$ \\
\hline \begin{tabular}{|l|} 
Logistics \\
Engineering \\
\end{tabular} & 53 & 57 & 9 & $16.98 \%$ & 11 & $19 \%$ \\
\hline $\begin{array}{l}\text { Chemical } \\
\text { Engineering and } \\
\text { Technology } \\
\end{array}$ & 28 & 75 & 6 & $21.43 \%$ & 15 & $20 \%$ \\
\hline $\begin{array}{l}\text { Pharmaceutical } \\
\text { Engineering }\end{array}$ & 32 & 57 & 4 & $12.50 \%$ & 1 & $2 \%$ \\
\hline Total & 854 & 2451 & 183 & $21.43 \%$ & 326 & $13 \%$ \\
\hline
\end{tabular}




\section{Conclusion}

The core of the Emerging Engineering Disciplines is to cultivate engineering professionals with the ability for cross-border integration, adapting to changes and leading those change. In-depth integration of industry and education, integration of science and education, and university-enterprise cooperative education should be fostered. The teaching chain from theoretical study to practice and then to inquiry learning should be established. The design activities are conducted throughout the whole process of teaching practice. Through exploration and reformation of practice content and teaching methods, building up a "talent cultivation as the center, practice and innovation-oriented" undergraduates practice teaching mode and strengthening the engineering students practice ability and innovation awareness training. It is of far-reaching significance to implement and promote university-enterprise cooperative education, so that to effectively guarantee student cultivation quality. Firstly, to strengthen university-enterprise education, university should provide enterprises with talent students, while enterprises should provide schools with places, jobs, financial resources, material and so on. Through students' practice in enterprise environment, we can cultivate the application technical personnel to achieve "win-win". Secondly, to improve the teaching and research capabilities of teachers and integrate business training and school knowledge. Teachers are required to have a higher ability and practical ability to solve practical problems, thereby prompting teachers to improve teaching quality. Thirdly, to improve students' capability of finding employment. Through the combination with the practice in enterprises, students can further understand their own shortcomings and advantages in their positions. On the hand, it is good for students to overcome shortcomings. On the other hand, it is beneficial for students to choose their career direction after graduation. Fourthly, to improve the levels of professional construction. The nature of jobs, as well as the business needs for students, and professional courses teaching should be combined to meet to the needs of society.

\section{$7 \quad$ Acknowledgement}

This paper is supported by Hubei Provincial Education Research Project, No.2015119.

\section{$8 \quad$ References}

[1] Wu, A. H.; Hou, Y. F.; et al. Accelerate Development and Construction of Emerging Engineering Disciplines, adapt to and Lead the New Economy. Education, 2017; 1, pp.1-8.

[2] Han, J. H.; Du, H.; et al. A new mode of cultivating excellent talents with universityenterprise cooperative education. Education Teaching Forum, 2015(13), pp.30-31.

[3] Wang, Q. H. Where is the Emerging Engineering Disciplines? Guangming Daily, April 03, $2017(05)$. 
[4] Li, W. W. Listening to "Emerging Engineering" Construction of Spring Thunder. China Education Press, April 17, 2017 (05).

[5] Qu, K. K. Why should there be "Emerging Engineering Disciplines ". People's Daily (in Chinese), April 21, 2017 (18).

[6] Gao, Y. Focus on the Training of Automation Students' Engineering Ability. Science and technology innovation guide, 2015; 5, pp.251-253.

[7] Gao, F. Y; Liu, H. The Practice Ability of the Joint Cultivation of Automated Undergraduate Students in the Joint Cultivation of Universities and Enterprises. Information systems engineering, 2010; p.136.

[8] Zhang, C. F. Innovation of the Cooperative Mechanism of University-Enterprise Cooperation to Develop the Advantages of Scientific Research in the Development of Packaging Characteristics of Automation Professionals, China packaging technology, 2008; 8, pp.52-54.

[9] Yu, W; Zhang, L. Research on Automation Professional Practice Teaching System of "University-enterprise Cooperation, Industrial Integration", Education Teaching BBS, 2012;9, pp.98-99.

[10] Lin, J. The School Enterprise Synergized the Research on the Cultivation Mode of Electric Automation Professionals, Education Modernization, 2017; 1pp.6-8.

[11] Xu, S; Xie, M; etc. Based on the "University-enterprise Cooperation" Model of College Automation Professional Curriculum Teaching Reform and Practice, Education Teaching BBS, $2012 ; 36$, pp.45-46.

\section{Authors}

Shan Zhong is section chief in Office of Academic Affairs of Wuhan University of Technology, Wuhan, China. She is responsible for the management of undergraduate students practical teaching.Email id: zhongshan@whut.edu.cn

Xinmin Zhou is a professor at School of Automation, Wuhan University of Technology, Wuhan, China. His research interests including Automatic Production Line, Engineering Management, Computer Network Monitoring and Image Processing. Email id: zhouxinmin2003@163.com

Article submitted 2019-01-04. Resubmitted 2019-03-03. Final acceptance 2019-03-06. Final version published as submitted by the authors. 